\title{
Management of Nora's Lesion: Case Series
}

\author{
Nora Lezyonunun Yönetimi: Vaka Serisi
Recep Öztürk¹, Şefik Murat Arıkan, Galip Beltir, Emin Kürşat Bulut, Ahmet Fevzi Kekeç, Bedii Şafak Güngör \\ ${ }^{1}$ Polatl1 State Hospital, Orthopedics and Traumatology, Ankara, Turkey \\ ${ }^{2}$ Ankara Dr Abdurrahman Yurtaslan Oncology Training and Research Hospital, Orthopedics and Traumatology, \\ Ankara, Turkey \\ ${ }^{3}$ Dortyol State Hospital, Orthopedics and Traumatology, Hatay, Turkey
}

Dergiye Ulaşma Tarihi: 30.03.2018 Dergiye Kabul Tarihi: 23.05.2018 Doi: 10.5505/aot.2018.37167

\section{ÖZET}

GİRiş ve AMAÇ: Nora'nın lezyonu olarak da bilinen bizarre parosteal osteokondromatöz proliferasyon, kemikten egzofitik büyüme ile kendini gösteren, benign bir lezyondur. Bu çalışmada, 2010-2018 yılları arasında tedavi edilen Nora lezyonuna sahip dört hastanın değerlendirilmesi ve kısa bir literatür taraması yapılarak güncel bilgilerin incelenmesi amaçlandi.

YÖNTEM ve GEREÇLER: Ortalama yaşları 32+24 std (26-37 yaş arası) olan iki erkek ve iki kadın toplam 4 hasta çalışmaya dahil edildi. Hastaların tanıya kadar geçen süre ve semptomları, klinik bulguları, kitle boyutu, MRI bulguları, cerrahi tedavileri, tedavi sonuçları ve komplikasyonlar incelendi.

BULGULAR: Tüm hastalara marginal eksizyon yapıldı. En sık kitle lokalizasyonu ön kolun uzun kemikleri idi. Bir vakada post-operatif 24. ayda rekürrens görüldü, nüks rezeksiyonu yapıldı. Diğer üç hastada takiplerinde nüks ya da komplikasyon görülmedi.

TARTIŞMA ve SONUÇ: Bizarre parosteal osteokondromatöz proliferasyon, vücudun birçok farklı lokalizasyonunda yerleşebilen, benign karaktere sahip ancak sık rekürrens ile karşımıza çıkabilen, nadir bir kemik lezyonudur. İyi bir preoperatif planlama ile yapılan dikkatli bir marginal eksizyon, nüksün önlenmesinde en önemli anahtardır.

Anahtar Kelimeler: Bizarre parosteal osteokondromatöz proliferasyon, Nora'nın lezyonu, radius, ulna, poplitea

\begin{abstract}
INTRODUCTION and OBJECTIVE: Also known as Nora lesion, bizarre parosteal osteochondromatous proliferation (BPOP) is a benign exophytic lesion originated from the bone. In this study, we aimed to evaluate four patients with Nora lesion who were evaluated between 2010 and 2018, and to review current information through a brief literature screening. MATERIAL and METHODS: A total of four patients with a mean age of $32 \pm 24$ years (26-37 years) including 2 female and 2 male patients were included in the study. Patients' time to diagnosis and symptoms, clinical findings, mass size, MRI findings, surgical treatments, treatment outcomes and complications were investigated.

RESULTS: Marginal excision was made to all the patients. The most common mass localization was the long bones of the forearm. Recurrence was developed in one patient at postoperative 24th month, and underwent relapse resection. The remaining three patients did not develop relapse or complications at follow-up. DISCUSSION and CONCLUSION: Bizarre parosteal osteochondromatous proliferation is a rare bone lesion, which may be localized in many different part of the body, has a benign character, but may be encountered with frequent recurrence. A careful marginal excision to performed with a good preoperative planning is the most crucial key in prevention of relapses.
\end{abstract}

Keywords: Bizarre parosteal osteochondromatous proliferation, Nora's lesion, radius, ulna, poplitea 


\section{INTRODUCTION}

Also known as Nora's lesion or periostitis ossificans, bizarre parosteal osteochondromatous proliferation (BPOP) is a rare lesion which was described for the first time by Nora et al. in 1983 [1-3]. Although so far BPOP has been reported in the literature many times as case reports, there are less than 10 case series in the literature on this issue [413].

BPOP is defined as a lesion containing bone, cartilage or fibrous tissue, and showing exophytic growth from the bone surface [5].

The most commonly involved regions are reported as phalanges, metacarpi and metatarsi, although rarely the lesions may also be seen in the long bones, skull, maxilla [6, 7]. In this study, we analyzed management of four BPOP cases with three localized in the long bones of the forearm, and one in the popliteal region, including the diagnosis, treatment and follow-up in the light of the current literature.

\section{MATERIAL and METHODS}

A screening which included only 'Nora' term was made on the Medline database from 2010 through 2018. Various search terms ('nora', 'periostitis ossificans', 'bizarre parosteal osteochondromatous proliferation (BPOP)') were used, including the combination of index and free text terms as recommended by Cochrane Handbook for Systematic Reviews of Interventions. The abstracts were screened and the relevant full text articles were further examined in details. References sections of the publications identified were screened for further literature review. All evidence levels were included.

\section{Case Reports}

\section{Case 1:}

A 29-year-old male patient presented to the outpatient clinic with the complaint of pain in the left forearm and palpable stiff swelling. He stated that the swelling has existed for about one year and increasingly grown. The patient had no history of trauma.

Direct radiograph ordered showed an irregular mass lesion originated from the radius (Figure I). Contrast enhanced forearm MRI revealed a regular and lobulated contoured mass lesion of $27 \times 25 \times 15 \mathrm{~mm}$ in the central region of the left forearm, which was in vicinity of the radius central diaphyseal cortex, showed exophytic growth to the soft tissue, and was seen as isointense on T1A sections, and hyperintense on T2A sections and enhanced after gadolinium. (Figure II).

Marginal excision of the mas was performed. Histopathologic examination was compatible with periostitis ossificans. No recurrence or complication was seen at the follow-up for 36 months.

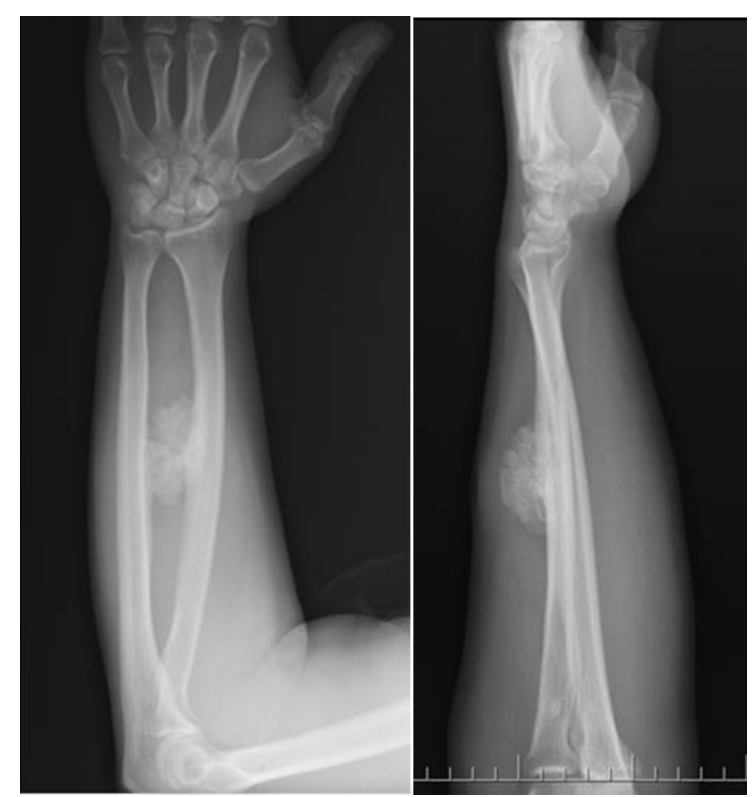

Figure I: Case 1, radius originated, irregular contoured mass lesion is seen on left forearm antero-postero-lateral direct radiography.

\section{Case 2:}

A 37-year-old female patient with occasional pain in the knee, stated that she had developed restrictions in her knee movements and her pain had increased in the last 8 months. She had no a history of trauma.

Her radiological investigations revealed a lobulated contoured mass lesion with heterogeneous inner structure, which filled the popliteal fossa, reached to a size of of $47 \times 73 \times 62 \mathrm{~mm}$ at the largest part, was seen as isointense on T1A sections, and isohyperintense on T2A sections, accompanied by signal free millimetric areas in the central region, and heterogeneously enhanced after the injection of intravenous contrast agent (Figure III). 


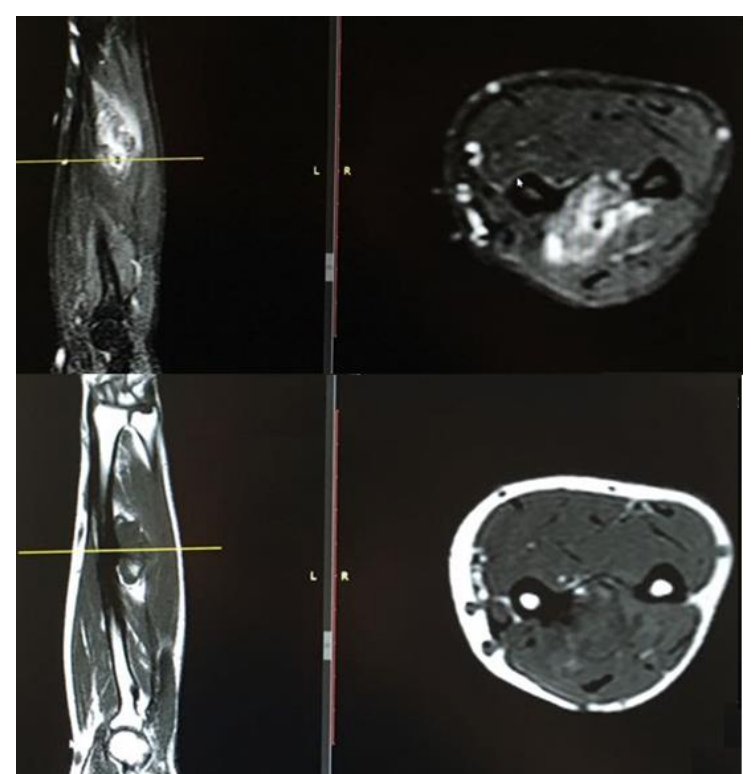

Figure II: Case 2, Magnetic resonance imaging shows a smooth and lobulated contoured mass of $27 \times 25 \times 19 \mathrm{~mm}$ with contrast enhancement after gadolinium in the central section of the left forearm, which was isointense with the muscles on T1A sequences, hyperintense on T2A sequences, showing vicinity with radius central diaphyseal cortex, and exophytic growth to the soft tissue.

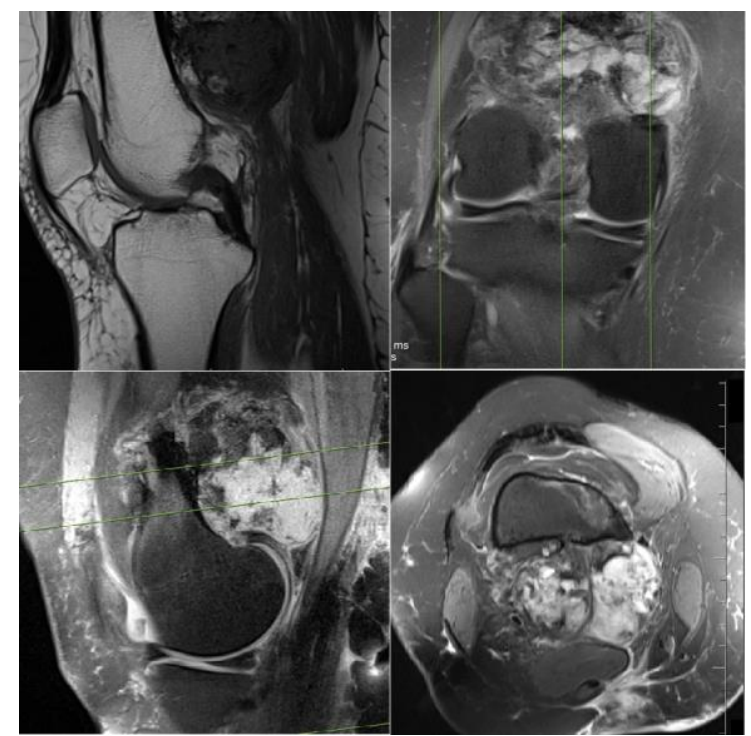

Figure III: Right knee Magnetic resonance imaging shows a lobulated contoured mass lesion which was isointense with the muscle on $\mathrm{T} 1$ sequences, and hyperintense compared to the muscle on $\mathrm{T} 2$ sequences.

Atypical condrocytes were observed in examination of the diagnostic biopsy material. The patient underwent wide tumor resection. Histopathological diagnosis was reported as bizarre parosteal osteochondromatous proliferation. The patient developed recurrence at the 24th month of the follow-up in the postoperative period. Recurrence resection was performed upon recurrent mass was detected in the investigations of the patient who presented with painful swelling localized in the incision line.

\section{Case 3:}

A 27-year-old female patient was referred to the orthopedics outpatient clinic with the complaints of swelling and pain in the right forearm. Radiological investigations of the patients revealed a lesion in the central of the right forearm, which was originated from the ulna, showed exophytic growth to the soft tissue, was seen as isointense on T1A sections, and hyperintense enhanced on T2A sections (Figure IV).

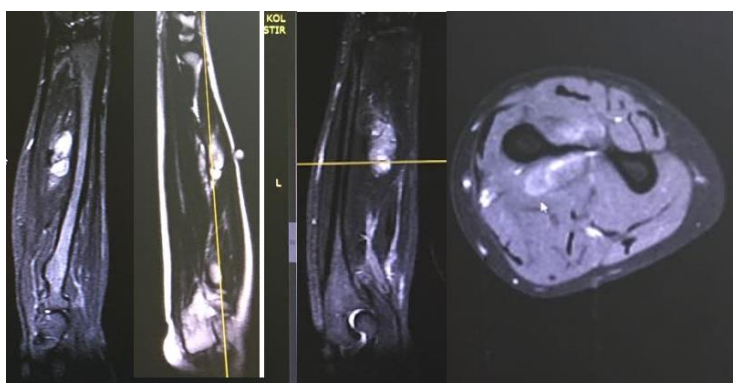

Figure IV: Case 3, right forearm Magnetic resonance imaging shows a lesion in the central section of the right forearm, arisen from the ulna, which which was isointense in T1A sequences, and hyperintense in T2A sequences, showing exophytic growth to the soft tissue.

The patient underwent marginal excision. Pathologic outcome was compatible with Nora's lesion. No recurrence was found at the last follow-up of the patient carried out at the 24th month. The patient was lost from the control in the next periods.

\section{Case 4:}

A 40-year-old male patient presented to the outpatient clinic with the complaint of swelling in the volar side of the left wrist. Physical examination revealed a mass lesion of approximately $3 \mathrm{~cm} 2$ in the volar side of the wrist. Neurovascular examination was normal. Direct radiography and MRI revealed a mass lesion of about $33 \times 23 \mathrm{~mm}$ in the palmar side of the wrist in the middle line interosseous area in distal vicinity of the radius and ulna, which

Adress for correspondence: Recep Öztürk, Polatlı State Hospital, Orthopedics and Traumatology, Ankara, Turkey

e-mail: ozturk recep@windowslive.com

Available at www.actaoncologicaturcica.com

Copyright $\odot$ Ankara Onkoloji Hastanesi 
was seen as isointense enhanced on T1A sections and hyperintense on T2A sections.

Tru-cut biopsy was performed, and the diagnosis was reported as chondroid lesion. Then, marginal excision of the mass was carried out. Pathologic outcome was compatible with Nora's lesion. No recurrence was found at the 6th month follow-up of the patients who are currently under our control.

\section{DISCUSSION}

There are at least 100 cases that were reported in the literature and one of them extensively evaluated these lesions regarding etiology, cytogenetic aberrations, radiographic interpretation and treatment [5]. Less than 10 of these studies have been presented as case series.

Bizarre parosteal osteochondromatous proliferation (BPOP) is a rare, reactive, mineralized mesenchymal benign lesion, affecting bone surfaces [8]. In the present study, we analyzed case reports and case series published on Medline in 2010 and later. This analysis included total 22 articles and 60 cases.

Although BPOP may be seen in any age, the most common age range has been reported as 20-30 years [9]. In our literature screening, age range was between newborn and 65 years old, and the mean age was found as 34.6 years unlike the literature. In the present study, mean age of 4 patients was 33.2 years.

Studies have reported similar rates of BPOP in among the sexes [10]. In our literature review also 29 cases were female and 31 male patients, in the present study.

This tumoral lesion has a benign pathology, although it may be mistaken for malignant lesions. Because it occasionally shows a rapid growth and a high incidence of recurrence [7].

In addition, the differential diagnosis includes parosteal osteosarcoma because of its parosteal localization [11]. Furthermore, it may be confused with osteochondroma because of being localized on the bone surface and having cartilaginous component. It can be distinguished by not showing continuity with medullary canal [12].

Horiguchi et al., suggested that mechanism of BPOP development is a lesion secondary to injury [9]. However, most cases in the literature had no-a history of trauma.

Whereas malignancy or metastasis has not been reported in almost all studies about BPOP, Choi et al. described a case of BPOP associated with fibrosarcoma in 2001 [13]. Treatment method is resection with wide margins in aggressive benign and malignant tumors, while marginal excision is performed in benign tumors $[14,15]$. No malignancy was found in our recent literature review and in the 4 patients in the current study [2-13, 16-18].

The current treatment method recommended for BPOP is marginal excision of symptomatic lesion. Intralesional excision is highly associated with recurrence [16]. We applied marginal excision in all of our patients after a careful preoperative planning.

High recurrence rates between 29\% and $55 \%$ at 2-year follow-up have been reported in the literature, and even it has been reported that about half of these recurrent cases were referred again due to a second recurrence $[1,17,18]$. In our study, one of four patients developed recurrence at follow-up, and thus the rate of recurrence was $25 \%$.

This study has several limitations. The study included data of a single center, and the number of patients was low because of the lesion being seen rarely. In addition, we evaluated the cases retrospectively. Further multicenter prospective studies with a larger number of patients are warranted.

\section{CONCLUSION}

Bizarre parosteal osteochondromatous proliferation (BPOP) is a rare bone lesion which may be localized in many different localizations of the body, and although being of benign character, it may be encountered with frequent recurrence. A careful marginal excision performed with a good preoperative planning, is the most important key in prevention of recurrence.

\section{REFERENCES}

1. Nora FE, Dahlin DC, Beabout JW. Bizarre parosteal osteochondromatous proliferations of the hands and feet. Am J Surg Pathol. 1983;7:245-50.

2. Kershen LM, Schucany WG, Gilbert NF. Nora's lesion: bizarre parosteal osteochondromatous 
proliferation of the tibia. Proc (Bayl Univ Med Cent). 2012;25(4):369-71.

3. Chaabane S, Chelli Bouaziz M, Ben Ghars KH, Abid L, Jaafoura MH, Ladeb MF. Bizarre Parosteal Osteochondromatous Proliferation: Nora's Lesion. Iran J Radiol. 2011;8(2):119-25.

4. Sökücü S, Aycan OE, Arıkan Y, Kabukçuoğlu YS. Congenital bizarre parosteal osteochondromatous proliferation in unusual location and age: a case report. Acta Orthop Traumatol Turc. 2016;50(1):120-4.

5. Doganavsargil B, Argin M, Sezak M, Kececi B, Pehlivanoglu B, Oztop F. A bizarre parosteal osteochondromatous proliferation (Nora's lesion) of metatarsus, a histopathological and etiological puzzlement Joint Bone Spine. 2014;81(6):537-40.

6. Kumar A, Khan SA, Sampath Kumar V, Sharma MC. Bizarre parosteal osteochondromatous proliferation (Nora's lesion) of phalanx in a child. BMJ Case Rep. 2014:23;2014.

7. Gruber G, Giessauf C, Leithner A, et al. Bizarre parosteal osteochondromatous proliferation (Nora lesion): a report of 3 cases and a review of the literature Can J Surg. 2008; 51(6): 486-9.

8. Rappaport A, Moermans A, Delvaux S. Nora's lesion or bizarre parosteal osteochondromatous proliferation: a rare and relatively unknown entity. JBR-BTR. 2014;97(2):100-2.

9. Horiguchi H, Sakane M, Matsui M, et al. Bizarre parosteal osteochondromatous proliferation (Nora`s lesion) of the foot. Pathol Int 2001;51:816-23.

10. HussainMM and Arif KS. Bizarre Parosteal Osteochondromatous Proliferation causing angular deformities: A Case ReportJ Orthop Case Rep. 2015; 5(1): 45-47.

11. Lindeque BG, Simson IW, Fourie PA. Bizarre parosteal osteochondromatous proliferation of a phalanx. Arch Orthop Trauma Surg 1990;110:58-60.

12. Torreggiani WC, Munk PL, Al-Ismail K, et al. MR imaging features of bizarre parosteal osteochondromatous proliferation of bone (Nora's lesion). Eur J Radiol 2001;40:224-31.

13. Choi JH, Gu MJ, Kim MJ, Choi WH, Shin DS, Cho KH. Fibrosarcoma in bizarre parosteal osteochondromatous proliferation. Skeletal Radiol. 2001;30(1):44-7.

14. Ozturk R., Arıkan ŞM, Şimşek MA,Özanlağan E, Güngör BŞ. Management of solitary fibrous tumors localized in extremity: case series and a review of the literature. Eklem Hastalik Cerrahisi 2017;28(2):121-7

15. Toğral G, Arıkan M, Aktaş E, Öztürk R, Güven O, Eksioğlu F. Surgical Management Of Bone Metastases From Urological Malignancies: An Analysis Of 70 Cases. Acta Orthop Traumatol Turc 2015;49(6):634-640

16. Rushing CJ, Rogers DE, Spinner SM, Gajzer DC. A Case Report of Heel Pain Mimicking Plantar Fasciitis and Osteosarcoma: A Unique Presentation of a Nora's Lesion. J Foot Ankle Surg. 2017;56(3):670-3.

17. Meneses MF, Unni KK, Swee RG. Bizarre parosteal osteochondromatous proliferation of bone (Nora's lesion). Am J Surg Pathol 1993;17:691-7.

18. Dhondt E, Oudenhoven L, Khan S, et al. Nora's lesion, a distinct radiological entity? Skeletal Radiol 2006;35:497-502. 